\title{
USULAN PERBAIKAN TATA LETAK PABRIK DAN MATERIAL HANDLING PADA PT. XYZ
}

\author{
I Wayan Sukania ${ }^{1}$, Silvi Ariyanti ${ }^{2}{\text { dan } \text { Nathaniel }^{1}}^{1}$ \\ ${ }^{1}$ Program Studi Teknik Industri Universitas Tarumanagara \\ ${ }^{2}$ Program Studi Teknik Industri Universitas Mercu Buana \\ e-mail: Nathaniel.liu87@gmail.com
}

\begin{abstract}
ABSTRAK
PT. XYZ merupakan sebuah perusahaan yang bergerak di indusustri manufaktur dengan memproduksi mainan plastik. PT. XYZ mempunyai tata letak pabrik dan sistem material handling yang baik namun terdapat masalah yang menyebabkan tata letak pabrik tersebut menjadi berantakan yang diantaranya terjadi ketidak sesuaian letak material bahan baku, material setengah jadi, produk jadi yang menyebabkan banyaknya tumpukan yang memakan ruangan di dalam ruang produksi, dan ruang packaging sehingga untuk mengatasi masalah tersebut perusahaan berencana untuk memperbaiki tata letak pabrik mereka terutama pada bagian ruang produksi dan ruang packaging dengan menggunakan metode Systematic Layout Planning (SLP) agar oabrik menjadi lebih rapi, efektif, dan efisien sehingga dapat meminimalkan waste time dan kegiatan transportasi bahan atau material dari suatu proses ke proses lain sehingga kinerja produktivitas produksi dapat menjadi maksimal. Hasil yang didapat dari analisis sistem material handling adalah indeks pekerja penangganan material secara manual sebesar 0,024 sedangkan hasil analisis sistem material handling dengan menggunakan boxes dan trolley adalah 0,0079 .
\end{abstract}

Kata kunci: Tata letak pabrik, material handling, Systematic Layout Planning.

\begin{abstract}
PT. XYZ is a company engaged in the manufacturing industry by producing plastic toys. PT. XYZ has a factory layout and material handling systems are good but there is a problem that causes the layout of the plant into disorganized that which occurred discrepancy lies the raw materials, the material of semifinished, finished products which caused the number of stacks which takes space in the production halls, and space packaging so as to resolve the issue the company plans to improve the layout of their factories mainly in the production space and space packaging using Systematic Layout Planning (SLP) in order manufacture become more orderly, effective, and efficient so as to minimize waste time and transport activities materials or materials from one process to another process so that manufacturing productivity performance can be maximized.. The results of the analysis of material handling system is the index of workers manually handling of the material by 0.024, while the results of the analysis of material handling systems using boxes and trolley is 0.0079 .
\end{abstract}

Keyword: Plant Layout, Material Handling, Systematic Layout Planning.

\section{PENDAHULUAN}

PT. XYZ merupakan sebuah perusahaan manufaktur yang memproduksi mainan plastik. PT. XYZ juga memiliki tata letak pabrik dan sistem material handling yang baik namun terdapat masalah yang menyebabkan tata letak pabrik tersebut menjadi berantakan yang diantaranya terjadi ketidak sesuaian pada letak material bahan baku, dan material lainnya yang memakan ruang ruang di dalam ruang produksi, dan ruang packaging.

Indentifikasi masalah yang terdapat pada PT. XYZ pada umumnya adalah penggunaan area pabrik yang kurang efektif dan efisien sehingga untuk mengatasi kendala tersebut, dilakukan penelitian di PT. XYZ untuk mengumpulkan data yang diperlukan dan mulai merancang usulan perbaikan tata letak pabrik dan sistem material handling pada PT. XYZ dengan berharap bahwa dengan adanya penelitian ini dapat menyelesaikan kendala yang ada di PT. XYZ dengan menghasilkan desain tata letak pabrik dan sistem material handling yang efektif dan efisien.

Tata letak (layout) dari fasilitas produksi dan area kerja merupakan elemen dasar yang sangat penting dari kelancaran proses produksi. Pengaturan tata letak di dalam pabrik merupakan aktivitas yang sangat vital dan sering muncul berbagai macam permasalahan di 
dalamnya. Tata letak pabrik disebut juga sebagai plant layout yang dapat diartikan sebagai tata cara pengaturan fasilitas-fasilitas guna menunjang kelancaran proses produksi [1].

Metode Systematic Layout Planning (SLP) diperkenalkan oleh Richard Muther pada tahun 1973, pendekatan ini banyak digunakan untuk berbagai macam persoalan dan metode penyelesaian yang meliputi beberapa tahapan antara lain problem produksi, transportasi, pergudangan, supporting service, dan aktivitasaktivitas yang dijumpai dalam perkantoran (office layout) [2].

Material handling adalah suatu seni dan ilmu untuk memindahkan, mengepack, dan menyimpan bahan-bahan atau barang dalam segala bentuk [3]. Selain itu menurut Rochman, et all, material handling bisa diartikan pula sebagai pergerakan, penyimpanan, perlindungan, dan pengendalian material baik di dalam penggunaan dan pembuangannya diseluruh proses manufaktur atau bisa juga diartikan sebagai penyedian material dalam jumlah, kondisi, posisi, waktu, dan tempat yang tepat untuk mendapatkan hasil yang maksimal dengan biaya yang minimum [4].

Material handling suatu kegiatan dalam memindahkan barang dan biasa juga dikatakan sebagai seni dan ilmu yang meliputi penanganan, pemindahan, pengepackan, penyimpanan, sekaligus pengendalian dari bahan atau material dengan segala bentuknya sehingga dapat disimpulkan bahwa material handling adalah salah satu jenis transportasi atau pengangkutan yang dilakukan dalam perusahaan industri yang artinya memindahkan bahan baku, barang setengah jadi atau barang jadi dari tempat awal ke tempat yang telah ditentukan. Pemindahan material dalam hal ini adalah bagaimana cara terbaik untuk memindahkan material dari satu tempat proses produksi ke proses produksi lainnya.

Untuk menghitung biaya material handling kita dapat mulai menghitung depresiasinya dengan menggunakan rumus sebagai berikut:

$$
\text { Depresiasi }=\frac{\text { Biaya Material Handling }}{\begin{array}{c}
\text { Umur Material Handling } \mathrm{x} \\
\text { lama beroperasi } \mathrm{x} \text { jam kerja) }
\end{array}}
$$

Yang dimana jarak pengangkutan tiap jam dapat dihitung dengan menggunakan rumus berikut:

Jarak Pengangkut $=\frac{\begin{array}{c}\text { Jarak yang ditempuh } \\ \text { selama } 1 \text { hari }\end{array}}{\text { an tiap jam }}$
Jam Kerja

Dimana, biaya material handling dapat dihitung dengan menggunakan rumus berikut:

Total Biaya $=$ Biaya Depresiasi + Biaya Operator

Dimana, biaya material handling per meternya dapat dihitung dengan menggunakan rumus berikut:

$\begin{array}{lc}\text { Biaya } \text { Material }= & \text { Total Biaya } \\ \text { Handling } / \mathrm{m} & \begin{array}{c}\text { Jarak Pengangkutan } \\ \text { Tiap Jam }\end{array}\end{array}$

Yang dimana Indeks pekerja penangganan material dapat dihitung dengan menggunakan rumus berikut:

$\mathrm{IPPM}=\frac{\mathrm{I}}{\mathrm{L}}$

Dimana:

I : Pekerja yang menanggani material.

L : Jumlah pekerja keseluruhan.

\section{METODE PENELITIAN}

Metodologi penelitian merupakan suatu tahapan yang harus dilakukan peneliti sebelum melakukan suatu penelitian, agar penelitian yang dilakukan dapat berjalan sesuai dengan rencana, dan menghasilkan hasil penelitian yang sesuai.

Di dalam melakukan penelitian digunakan beberapa alat ukur untuk mendapatkan informasi mengenai penelitian yang diantaranya adalah mengamati secara langsung dan wawancara dengan pihak pabrik sehingga dapat disimpulkan dan memulai penelitian untuk menyusun laporan dengan menggunakan metode-metode yang efektif dan efisien mengenai topik penelitian.

Pemilihan metode akan dilakukan saat menyusun metodologi penelitian terdiri dari 
beberapa tahapan umum seperti pada dasarnya. Tahapan pengerjaan dapat dilihat pada Gambar 1.



Gambar 1. Flowchart Metodologi Penelitian

\section{HASIL DAN PEMBAHASAN}

Berikut data-data yang dikumpulkan pada saat melakukan penelitian, data-data dapat dilihat pada Tabel 1.

Perancangan tata letak pabrik, yaitu dengan pembuatan Activity Relation Chart (ARC) dan Activity Relation Diagram (ARD) untuk bagian ruang produksi serta secara keseluruhan pabrik dengan menggunakan algortima relationship diagramming. Pada pembuatan Activity Relation Chart (ARC), terdapat penggunaan kode-kode alasan untuk mempermudah peneliti dalam menganalisis hubungan antar departemen baik untuk ruang produksi serta secara keseluruhan pabrik. Berikut deskripsi kode alasan yang diberikan pada pembuatan Activity Relation Chart, dapat dilihat pada Tabel 2.

Tabel 1. Data Pengamatan.

\begin{tabular}{|c|c|}
\hline $\begin{array}{l}\text { Kapasitas Produksi } \\
\text { per Bulan }\end{array}$ & 30,6 ton \\
\hline Hari Kerja per Bulan & 22 hari \\
\hline Jam Kerja per Hari & 8 jam \\
\hline Produksi per Jam & $\frac{30,6 \times 1000 \mathrm{~kg}}{22 \text { hari } \times 8 \mathrm{jam}}=173.86 \mathrm{~kg} / \mathrm{jam}$ \\
\hline Reliabilitas & $85 \%$ \\
\hline Efisiensi Pabrik & $95 \%$ \\
\hline $\begin{array}{l}\text { Waktu Set Up Mesin } \\
\text { (per minggu) }\end{array}$ & 30 menit \\
\hline
\end{tabular}

Tabel 2 Deskripsi Kode Alasan.

\begin{tabular}{cl}
\hline $\begin{array}{c}\text { Kode } \\
\text { Alasan }\end{array}$ & Deskripsi Kode Alasan \\
\hline 1 & Urutan aliran material/proses \\
2 & Mengurangi waktu menunggu \\
3 & Keamanan dan keselamatan \\
4 & Penggunaan catatan kerja yang sama \\
5 & Mempermudah pengawasan \\
6 & Mengganggu kegiatan produksi \\
7 & Memudahkan pemindahan produk dan \\
& material \\
8 & Penggunaan tenaga kerja yang sama \\
9 & Memudahkan koordinasi karyawan \\
\hline
\end{tabular}

Berikut Activity Relationship Chart pada Ruang Produksi dapat dilihat pada Gambar 2 dan ARC Keseluruhan Pabrik dapat dilihat pada Gambar 3

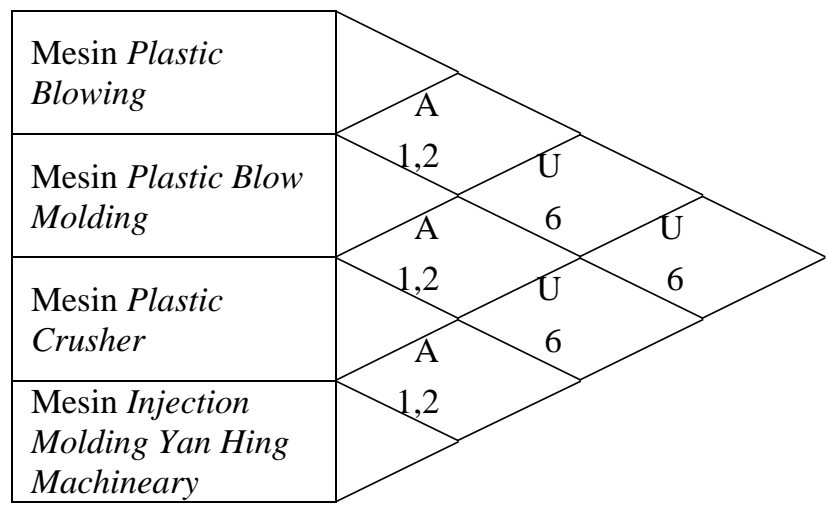

Gambar 2. ARC Ruang Produksi.

Berikut worksheet ARC pada Ruang Produksi dapat dilihat pada Tabel 3 dan worksheet ARC keseluruhan pabrik dapat dilihat pada Tabel 4. 
Pada Gambar 4 dapat dilihat ARD Proses Produksi dan ARD Keseluruhan Pabrik dapat dilihat pada Gambar 5.
Tabel 3. Worksheet ARC Ruang Produksi.

\begin{tabular}{ccccc}
\hline Relationship & 1 & 2 & 3 & 4 \\
\hline A & 2 & 1,3 & 2,4 & 3 \\
E & - & - & - & - \\
I & - & - & - & - \\
O & - & - & - & - \\
U & 3,4 & 4 & 1 & 1,2 \\
X & - & - & - & - \\
\hline
\end{tabular}

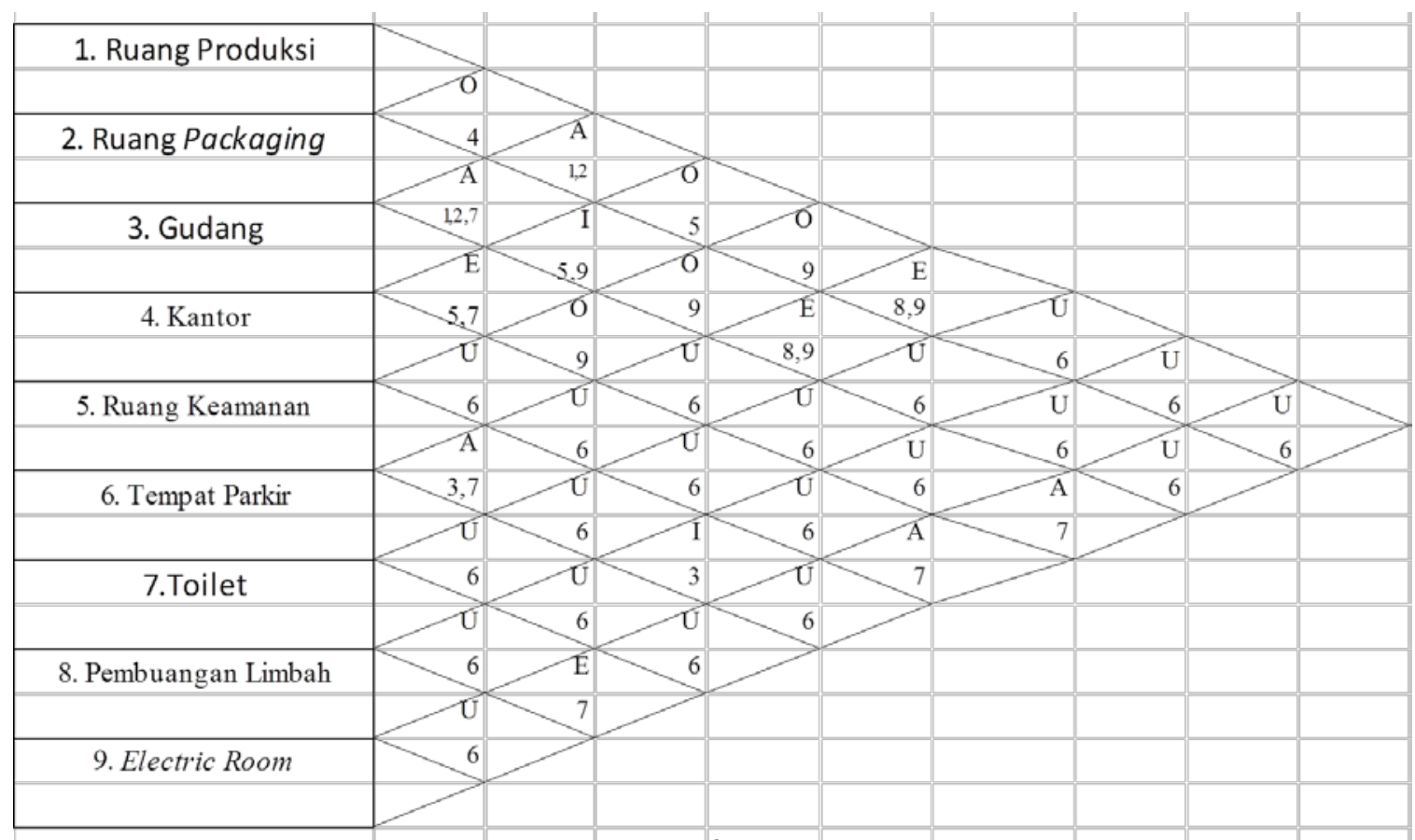

Gambar 3. ARC Keseluruhan Pabrik

Tabel 4. Worksheet ARC Keseluruhan Pabrik.

\begin{tabular}{|c|c|c|c|c|c|c|c|c|c|}
\hline \multicolumn{10}{|c|}{ Work Sheet Diagram } \\
\hline Relationship & 1 & 2 & 3 & 4 & 5 & 6 & 7 & 8 & 9 \\
\hline $\mathrm{A}$ & 2,3 & 3 & $1.24,9$ & 9 & 6 & 5 & - & - & 3,4 \\
\hline $\mathrm{E}$ & - & - & - & 3 & - & 1,2 & 9 & - & 7 \\
\hline I & - & 4,6 & - & 2 & - & - & - & 5 & - \\
\hline $\mathrm{O}$ & $2,4,5$ & 1,5 & 5 & 1 & $1,2,3$ & - & - & - & - \\
\hline $\mathrm{U}$ & $6,8,9$ & $7,8,9$ & $6,7,8$ & $5,6,7,8$ & $4,7,9$ & $3,4,7,8,9$ & $1,2,4$ & $1,2,4$ & $1,2,6$ \\
\hline$X$ & - & - & - & - & - & - & - & - & - \\
\hline
\end{tabular}

\begin{tabular}{|c|c|c|c|}
\hline $\begin{array}{l}\text { A-2 } \\
\quad \cup-3,4\end{array}$ & $\begin{array}{cc}A-1,3 & E- \\
U-4 & \end{array}$ & $\begin{array}{cc}\text { A-2,4 } & \text { E- } \\
U-1 & \end{array}$ & $\begin{array}{ll}\text { A-3 } & \text { E- } \\
U-1,2 & \end{array}$ \\
\hline $\begin{array}{l}\text { 1. Mesin Plastic } \\
\text { Blowing } \\
\times-\end{array}$ & $\begin{array}{l}\text { 2. Mesin Platic Blow } \\
\text { Molding } \\
\mathrm{X}-\end{array}$ & $\begin{array}{l}\text { 3. Mesin Plastic } \\
\text { Crusher } \\
\text { X- }\end{array}$ & $\begin{array}{l}\text { 4. Mesin Yan Hing } \\
\text { Machineary } \\
\mathrm{X}-\end{array}$ \\
\hline O- & O- & O- & O- \\
\hline
\end{tabular}

Gambar 4. ARD Proses Produksi. 




Gambar 5. ARD Keseluruhan Pabrik.

Perhitungan luas area produksi, Gudang bahan baku, gudang bahan jadi, luas kantor dan plant service dapat dilihat pada Tabel 5 dan

Dan usulan perbaikan tata letak pabrik Tabel 6.

Tabel 5. Luas Area Produksi

\begin{tabular}{|c|c|c|c|c|c|c|c|c|c|c|c|c|c|c|c|c|c|}
\hline & & \multicolumn{16}{|c|}{ Area Material } \\
\hline & & \multicolumn{3}{|c|}{ Ukuran Mesin(m) } & \multicolumn{3}{|c|}{ Area Operator (m) } & \multicolumn{3}{|c|}{ Input } & \multicolumn{3}{|c|}{ Output } & \multirow{2}{*}{$\begin{array}{l}\text { Jumlah } \\
\text { Mesin } \\
\text { (unit) }\end{array}$} & \multirow{2}{*}{$\begin{array}{c}\text { Total } \\
\text { Luas } \\
\text { Area } \\
\text { Tiap } \\
\text { Proses } \\
\left(\mathrm{m}^{2}\right) \\
\end{array}$} & \multirow{2}{*}{$\begin{array}{c}\text { Allowance } \\
200 \%\end{array}$} & \multirow{2}{*}{$\begin{array}{l}\text { Total Luas } \\
\text { Area tiap } \\
\text { Proses } \\
+ \text { Allowance }\end{array}$} \\
\hline \multirow{2}{*}{\multicolumn{2}{|c|}{$\begin{array}{l}\text { Plastic } \\
\text { Blowing } \\
\text { Machine }\end{array}$}} & $\mathrm{Pj}$ & $\mathrm{Lb}$ & $\mathrm{Lu}$ & $\mathrm{Pj}$ & $\mathrm{Lb}$ & $\mathrm{Lu}$ & $\mathrm{Pj}$ & $\mathrm{Lb}$ & $\mathrm{Lu}$ & $\mathrm{Pj}$ & $\mathrm{Lb}$ & $\mathrm{Lu}$ & & & & \\
\hline & & 2,4 & 1,1 & 2,64 & 1 & 1 & 1 & 2 & 1.5 & 3 & 2 & 1,5 & 3 & 5 & 48,2 & 96,4 & 144,6 \\
\hline \multicolumn{2}{|c|}{$\begin{array}{l}\text { Plastic Blow } \\
\text { Molding }\end{array}$} & 3 & 2 & 6 & 1 & 1 & 1 & 0 & 0 & 0 & 1.5 & 1,5 & 2,25 & 1 & 9,25 & 18,5 & 27,75 \\
\hline \multicolumn{2}{|c|}{$\begin{array}{l}\text { Plastic } \\
\text { Crusher }\end{array}$} & 1,1 & 1 & 1,1 & 1 & 1 & 1 & 0 & 0 & 0 & 2 & 2 & 4 & 4 & 24,4 & 48,8 & 73,2 \\
\hline \multicolumn{2}{|c|}{$\begin{array}{l}\text { Yan Hing } \\
\text { Machineary }\end{array}$} & 7,1 & 1,4 & 9,94 & 1 & 1 & 1 & 2 & 1,5 & 3 & 1 & 1 & 1 & 12 & 179,28 & 358,56 & 537,84 \\
\hline \multicolumn{2}{|c|}{ Packaging } & 1,9 & 0,5 & 0,95 & 1 & 1 & 1 & 0 & 0 & 0 & 0.2 & 0,2 & 0,04 & 16 & 31,84 & 63,68 & 95,52 \\
\hline \multicolumn{14}{|c|}{ Keterangan: Pj=Panjang (m), Lb=Lebar (m), Lu=Luas $\left(\mathrm{m}^{2}\right)$} & \multicolumn{3}{|c|}{ Total Luas Area Produksi } & 878,91 \\
\hline \multicolumn{18}{|c|}{ Tabel 6. Luas Gudang Bahan Baku } \\
\hline \multirow{2}{*}{\multicolumn{2}{|c|}{ No $\quad$ BB }} & \multirow{2}{*}{\multicolumn{2}{|c|}{$\begin{array}{l}\text { Kebutuhan } \\
\text { per mgg (kg) }\end{array}$}} & \multirow{2}{*}{\multicolumn{2}{|c|}{$\begin{array}{l}\text { Persediaan } \\
\text { (mgg) }\end{array}$}} & \multirow{2}{*}{\multicolumn{2}{|c|}{$\begin{array}{l}\text { Kebutuhan per } \\
\text { bulan (kg) }\end{array}$}} & \multirow{2}{*}{\multicolumn{2}{|c|}{$\begin{array}{l}\text { Berat per } \\
\text { kemasan } \\
(\mathrm{kg})\end{array}$}} & \multirow{2}{*}{\multicolumn{2}{|c|}{$\begin{array}{l}\text { Perkiraan } \\
\text { jumlah } \\
\text { kemasan } \\
\text { (kemasan) }\end{array}$}} & \multirow{2}{*}{$\begin{array}{l}\text { Ukuran } \\
\text { kemasan } \\
\left(\mathrm{m}^{3}\right)\end{array}$} & \multirow{2}{*}{\multicolumn{2}{|c|}{$\begin{array}{c}\text { Jumlah kemasan } \\
\text { per tumpukan } \\
\text { (kemasan/tump) }\end{array}$}} & \multicolumn{2}{|c|}{$\begin{array}{l}\text { Luas area yang } \\
\text { diperlukan }\end{array}$} & \multirow{2}{*}{$\begin{array}{c}\text { Luas Area } \\
\text { yang } \\
\text { diperkirakan } \\
+ \text { allowance } \\
(200 \%)\left(\mathrm{m}^{2)}\right.\end{array}$} \\
\hline & & & & & & & & & & & & & & & $\begin{array}{l}\text { Area } \\
\left(\mathrm{m}^{2}\right)\end{array}$ & $\begin{array}{l}\text { Vol } \\
\left(\mathrm{m}^{3}\right)\end{array}$ & \\
\hline 1 & $\begin{array}{c}\text { Biji } \\
\text { Plastik }\end{array}$ & \multicolumn{2}{|c|}{7.650} & \multicolumn{2}{|c|}{4} & \multicolumn{2}{|c|}{30.600} & \multicolumn{2}{|c|}{30} & \multicolumn{2}{|c|}{1.020} & 0,105 & & 10 & 35,7 & 20,71 & 107,1 \\
\hline 2 & $\begin{array}{l}\text { Balok } \\
\text { Lego }\end{array}$ & \multicolumn{2}{|c|}{4.370} & & 1 & 4.3 & & 30 & & 145,6 & & 0,15 & & 5,6608 & 7,41 & 3,93 & 22,23 \\
\hline
\end{tabular}



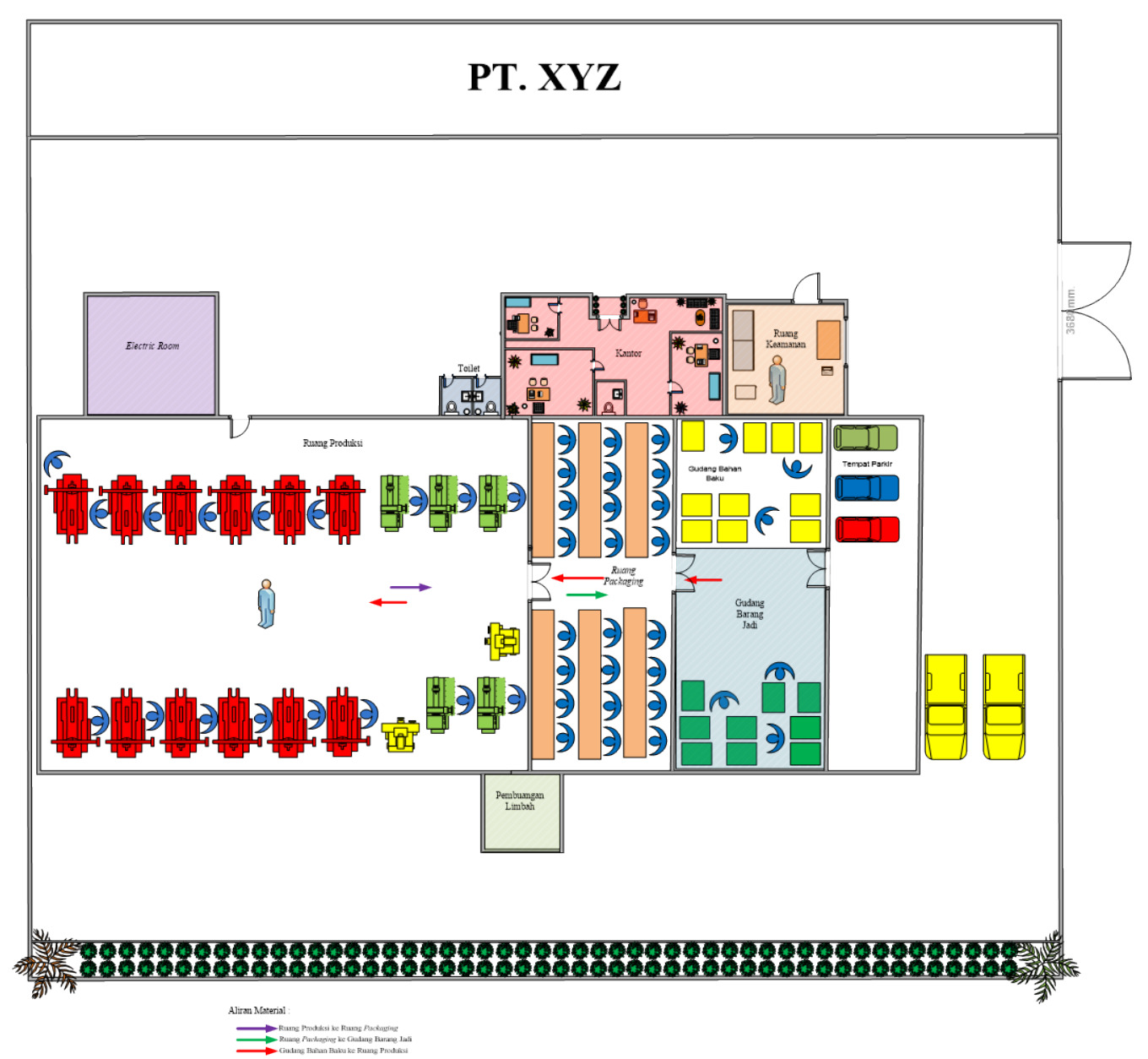

Gambar 6. Template atau Skema Layout Pabrik.

Sistem material handling yang diterapkan di PT. XYZ adalah menggunakan tenaga kerja secara manual untuk mengangkat beban dan memindahkan bahan baku dan barang jadi yang dapat dilihat pada Gambar 7.

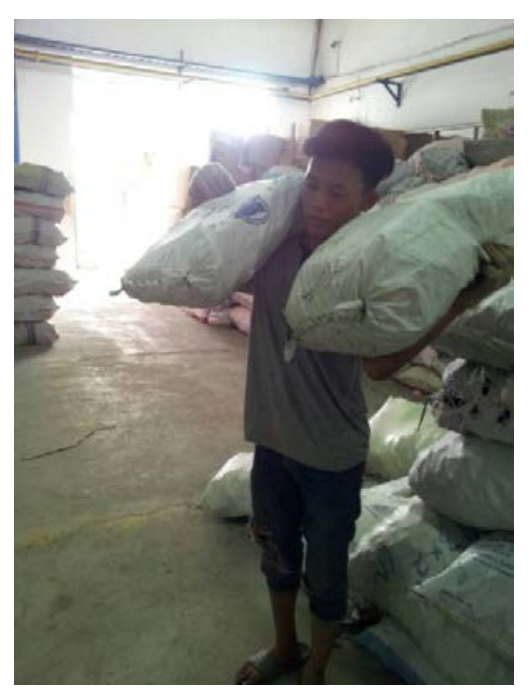

Gambar 7. Proses Memindahkan Barang Jadi Secara Manual.
Kemudian dicoba menerapkan hal yang sederhana untuk meningkatkan produktivitas dan mengurangi frekuensi bolak-balik karyawan dengan memindahkan barang jadi dengan menggunakan boxes dan trolley yang dapat dilihat pada Gambar 8 dan 9.



Gambar 8. Boxes 


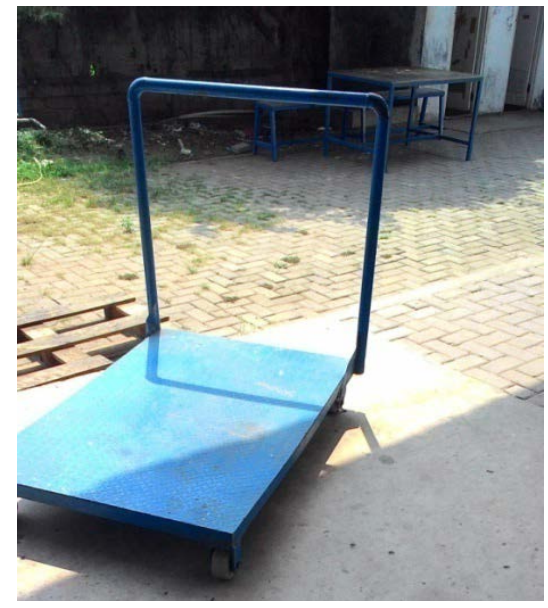

Gambar 9. Trolley.

Dari pengamatan yang dlakukan kemudian dihitung berapa kali buruh tersebut bolak-balik mengantarkan bahan jadi dari ruang produksi ke ruang packaging secara manual dan menggunakan boxs dan trolley yang dapat ditunjukkan pada Tabel 7.

Tabel 7. Data pengamatan

\begin{tabular}{ccc}
\hline Hari & Manual & Boxes dan trolley \\
\hline 1 & $117 \mathrm{kali}$ & $39 \mathrm{kali}$ \\
2 & $129 \mathrm{kali}$ & $43 \mathrm{kali}$ \\
3 & $120 \mathrm{kali}$ & $40 \mathrm{kali}$ \\
4 & $114 \mathrm{kali}$ & $38 \mathrm{kali}$ \\
5 & $123 \mathrm{kali}$ & $41 \mathrm{kali}$ \\
\hline
\end{tabular}

Namun secara umumnya dari data pengamatan dapat diperoleh analisis perinciaan biaya material handling yang dapat dilihat sebagai berikut:

Analisis biaya material handling secara manual dapat dilihat sebagai berikut:

- Keterangan UMP Jakarta = Rp. 2.600.000,-

- Jarak dari ruang produksi ke ruang packaging $=24 \mathrm{~m}$.

- Rata-rata bolak balik untuk untuk 3 orang pekerja $=121$ kali.

- Jarak tempuh $=121 \times 24 \mathrm{~m}=2.904 \mathrm{~m}$.

- Upah 1 jam kerja $=\frac{\text { Rp.2.600.000 }}{22 \text { hari } 8 \text { jam }}$

$=$ Rp. $14.772,73$

- $\quad$ Harga Tenaga Kerja = Rp. 2.600 .000 x 3

$=$ Rp. 7.800 .000

- Upah 3 orang tenaga kerja/jam

$$
=\frac{\text { Rp. } 7.800 .000}{22 \text { hari } 8 \text { jam }}=\text { Rp. 44.318,18/jam }
$$

- Upah 3 orang tenaga kerja/m

$$
=\frac{\mathrm{Rp} .44318 .18 / \mathrm{jam}}{363 \mathrm{~m} / \mathrm{jam}}=\mathrm{Rp} \cdot 122,08 / \mathrm{m}
$$

- Jarak pengangkutan tiap jam

$$
\begin{aligned}
& =\frac{\text { Jarak yang di tempuh selama } 1 \text { hari }}{\text { Jam Kerja }} \\
& =\frac{2.904 \mathrm{~m}}{8 \mathrm{jam}}=363 \mathrm{~m} / \mathrm{jam}
\end{aligned}
$$

- $\quad$ Total Biaya = Biaya 3 orang tenaga kerja $=$ Rp. 44.318.18/jam

- Biaya material handling/m

$$
\begin{aligned}
& =\frac{\text { Total Biaya }}{\text { Jarak pengangkutan tiap jam }} \\
& =\frac{\text { Rp. } 44.318,18}{24 \mathrm{~m}} \\
& =\text { Rp. } 1.846 .59 / \mathrm{m}
\end{aligned}
$$

- Indeks pekerja penanggung material (IPPM)

$$
\begin{aligned}
& =\frac{3}{127} \\
& =0,024
\end{aligned}
$$

Analisis biaya material handling dengan menggunakan boxes dan trolley dapat dilihat sebagai berikut:

- Keterangan UMP Jakarta = Rp. 2.600.000,-

- Jarak dari ruang produksi ke ruang packaging $=24 \mathrm{~m}$.

- Rata-rata bolak balik untuk seorang pekerja menggunakan sistem material handling = 41 kali.

- Jarak tempuh $=41 \times 24 \mathrm{~m}=984 \mathrm{~m}$.

- $\quad$ Upah 1 jam kerja $=\frac{\text { Rp.2.600.000 }}{22 \text { hari } \times 8 \text { jam }}$ $=$ Rp. 14.772,73

- Harga Trolley = Rp. 1.170.000

- Harga Boxes = Rp. 160.000 x 6 boxes

$$
=\text { Rp. } 960.000
$$

- Total biaya material handling

= Harga Trolley + Harga Boxes

$=$ Rp. $1.170 .000+$ Rp. 960.000

$=$ Rp. 2.130 .000

- Depresiasi

$$
\begin{aligned}
= & \frac{\text { Biaya Material Handling }}{\text { Umur Material Handling } \mathrm{x}} \\
\text { lama beroperasi } \mathrm{x} \text { jam kerja } & \frac{\text { Rp.2.130.000 }}{264 \text { hari x } 8 \text { jam }} \\
= & \text { Rp. } 1.008,52 / \text { jam }
\end{aligned}
$$

- Jarak pengangkutan tiap jam

$=\frac{\text { Jarak yang ditempuh selama } 1 \text { hari }}{\text { Jam Kerja }}$

$$
\begin{aligned}
& =\frac{984 \mathrm{~m}}{8 \mathrm{jam}} \\
& =123 \mathrm{~m} / \mathrm{jam}
\end{aligned}
$$


- Total Biaya

$$
\begin{aligned}
& =\text { Biaya Depresiasi + Biaya Operator } \\
& =\text { Rp. 1.008,52 + Rp. 147.772,73 } \\
& =\text { Rp. 15.781,25/jam }
\end{aligned}
$$

- Biaya material handling/m

$$
\begin{aligned}
& =\frac{\text { Total Biaya }}{\text { Jarak pengangkutan tiap jam }} \\
& =\frac{\text { Rp.15781.25 }}{24 \mathrm{~m}} \\
& =\text { Rp. } 657,55 / \mathrm{m}
\end{aligned}
$$

- Indeks pekerja penanganan material (IPPM)

$$
\begin{aligned}
& =\frac{\mathrm{I}}{\mathrm{L}} \\
& =\frac{1}{127}=0,0079
\end{aligned}
$$

\begin{tabular}{|c|c|c|}
\hline Keterangan & Manual & $\begin{array}{l}\text { Boxes dan } \\
\text { trolley }\end{array}$ \\
\hline Jarak Tempuh & $2.904 \mathrm{~m}$ & $984 \mathrm{~m}$ \\
\hline $\begin{array}{l}\text { Jarak Pengangkutan } \\
\text { tiap jam }\end{array}$ & 363 m/jam & $123 \mathrm{~m} / \mathrm{jam}$ \\
\hline Total Biaya & $\begin{array}{c}\text { Rp. } \\
44.318,18 / \text { jam }\end{array}$ & $\begin{array}{c}\text { Rp. } \\
15.781,25 / \mathrm{jam}\end{array}$ \\
\hline $\begin{array}{l}\text { Biaya Material } \\
\text { Handling/m }\end{array}$ & Rp. $1856.59 / \mathrm{m}$ & Rp. 657,55/m \\
\hline $\begin{array}{l}\text { Indeks Pekerja } \\
\text { Penangganan } \\
\text { material }\end{array}$ & 0,024 & 0,0079 \\
\hline
\end{tabular}

Sehingga berdasarkan dari analisis di atas kita dapat mengetahui perubahan yang dihasilkan dari penerapan sistem material handling ini yang dapat dilihat pada Tabel 8.

Tabel 8. Hasil implementasi

Dari hal perhitungan tersebut maka biaya pemindahan material dapat di minimalisasi dan dengan di terapkan hal tersebut maka kegiatan memindahkan material dapat berkurang karena buruh angkut tersebut tidak perlu terlalu sering bolak-balik mengantarkan bahan jadi dari ruang produksi ke ruang packaging.

\section{KESIMPULAN}

Dari hasil penelitian ini diperoleh total luas area secara keseluruhan pabrik yaitu seluas $1.121,78 \mathrm{~m}^{2}$. Total luas area ini sudah mencakup Gudang Bahan Baku, Gudang Barang Jadi, Ruang Produksi, Kantor, Ruang
Keamanan, Tempat Parkir, Electirc Room, dan Pembuangan Limbah. Dari penerapan sistem material handling yang diterapkan diperoleh bahwa sistem material handling dengan menggunakan boxes dan trolley memiliki nilai dan hasil yang jauh lebih baik dibandingkan dengan manual. Hasil penerapan atau implementasi sistem material handling tersebut dapat dilihat sebagai berikut: Secara manual: Jarak tempuh $=2.904 \mathrm{~m}$ Jarak pengangkutan tiap jam $=363 \mathrm{~m} / \mathrm{jam}$ Total biaya $=\mathrm{Rp}$. 44.318,18/jam Biaya material handling $/ \mathrm{m}=\mathrm{Rp}$. $1.846,59 / \mathrm{m}$ Indeks pekerja penangganan material $=0,024$ Dengan boxes dan trolley: Jarak tempuh $=984 \mathrm{~m}$ Jarak pengangkutan tiap jam $=123 \mathrm{~m} / \mathrm{jam}$ Total biaya $=\mathrm{Rp}$. 15.781,85/jam Biaya material handling/m = Rp. $657,55 / \mathrm{m}$ Indeks pekerja penangganan material $=0,0079$

\section{DAFTAR PUSTAKA}

[1]. Apple James M. 1990. Tata Letak Pabrik dan Pemindahan Bahan. Edisi Ketiga. ITB Bandung.

[2] Wignjosoebroto, Sritomo. 2003. Tata Letak Pabrik dan Pemindahan Bahan, edisi ketiga. Surabaya: Widya Guna.

[3]. Tompkins, James A, John A. White, et al. 1996. Facilities Planning. Wiley: United States of America.

[4]. Rochman, Taufiq; R. D. Astuti; dan R. Patriansyah. 2010. Peningkatan Produkstivitas Kerja Operator melalui Perbaikan Alat Material Handling dengan Pendekatan Ergonomi. Performa, 9(1):1-10. 